\title{
Congenital cervical spinal stenosis
}

INSERM

\section{Source}

INSERM. (1999). Orphanet: an online rare disease and orphan drug data base. Congenital cervical spinal stenosis. ORPHA:831

Cong enital cervical spinal stenosis is a rare neurological disease characterized by a congenital narrowing of the bony anatomy of the cervical spinal canal (saggital diameter $<14 \mathrm{~mm}$ ), predisposing the individual to symptomatic neural compression, such as cramps, paresthesias, pain, muscle hypertonia and weakness, myelopathy and sphincter disturbances. 